\title{
Hoya undulata (Apocynaceae, Asclepiadoideae), a new myrmecophytic species from Borneo, and typification of $\boldsymbol{H}$. darwinii
}

\author{
S. Rahayu ${ }^{1}$, U. Meve ${ }^{2} \&$ M. Rodda ${ }^{3}$ \\ ${ }^{1}$ Bogor Botanic Gardens, Indonesian Institute of Sciences, \\ Bogor, Indonesia \\ srirahayukrb@yahoo.com \\ ${ }^{2}$ Department of Plant Systematics, University of Bayreuth, \\ 95440 Bayreuth, Germany \\ ${ }^{3}$ Herbarium, Singapore Botanic Gardens, National Parks Board, \\ 1 Cluny Road, 259569 Singapore \\ rodda.michele@gmail.com
}

\begin{abstract}
In this paper we document the discovery of a new Hoya species from Borneo, H. undulata S.Rahayu \& Rodda. The leaves of the new species form domatia, specialised structures harbouring ants, previously only observed in Hoya mitrata Kerr and $H$. darwinii Loher. The corona is unique among Bornean Hoya species as its lobes develop two lateral hooked appendages, also present in $H$. griffithii Hook.f, a species from mainland Asia. A lectotype for Hoya darwinii is also selected.
\end{abstract}

Keywords. Ant plant, domatia, heath forest, Hoya mitrata, Indonesia, myrmecophyte, West Kalimantan

\section{Introduction}

Hoya R.Br. is a poorly known tropical genus for which a modern revision is lacking. Extensive field investigations and accurate documentation of new species are essential before a generic revision can be compiled (Rodda \& Ercole, 2014). In Borneo, Merrill (1921) listed only eight Hoya species and more recently Forster et al. (1998) described the diversity of the genus in Borneo as 'unknown'. Recently, new taxa have been described based on collections from Sabah (e.g. Lamb et al., 2014; Rodda et al., 2013) and to a lesser extent, Sarawak (Rodda \& Simonsson, 2011a, b; Rodda \& Simonsson Juhonewe, 2013a). The higher number of novelties described from Sabah is directly linked to efforts by the staff at Kipandi Park (Kampung Kipandi, Moyog, Sabah) to cultivate wild-collected sterile specimens until they bloom so that they can be identified (Lamb et al., 2014), an approach successfully adopted by Rintz (1978) in Peninsular Malaysia. Among the species described in Lamb et al. (2014) only Hoya sammannaniana A.Lamb et al. is also found in Kalimantan. Two further species, Hoya rintzii Rodda \& Simonsson and Hoya beccarii Rodda \& Simonsson can be found throughout Borneo and are widespread elsewhere in SE Asia (Rodda \& Simonsson 
Juonewe, 2013b; Rodda et al., 2014). The diversity of Hoya in Indonesian Borneo is least known due to the scarcity of recent collections; the only information on Hoya diversity in Central Kalimantan can be found in Rahayu (2006) who lists only nine species. Lamb et al. (2014) suggested that 60 to 70 Hoya species may occur in Sabah alone and it is becoming apparent that the diversity of Hoya of Borneo is expected to be comparable to or exceeding that of the Philippines with 104 species (Aurigue et al., 2013) or of New Guinea with 74 species (Forster, 1996).

During a recent expedition in West Kalimantan Mr Sulaiman Hasim discovered a new Hoya species that we formally describe and illustrate here. It is compared with the vegetatively similar Hoya darwini and $H$. mitrata. The latter was lectotypified in Rodda (2012) while the former is here lectotypified.

Hoya undulata S.Rahayu \& Rodda sp. nov.

Similar to Hoya mitrata Kerr and $H$. darwinii Loher when sterile because it has specialised convex leaves forming multileaved domatia. Easily separated when fertile because the flowers have a rotate corolla formed by almost completely free corolla lobes, while Hoya mitrata and $H$. darwinii have reflexed corollas with a tube almost as long as the lobes. - TYPE: Indonesia, West Kalimantan, Putussibau, 300-380 m, on a slope above a stream, February 2014, Sulaiman Hasim s.n. (holotype BO). (Fig. 1, 2)

Epiphytic climber with white latex in all vegetative parts, glabrous. Stems slender, internodes very variable in length, from $0.5 \mathrm{~cm}$ in the parts of the vine forming domatia, to $20 \mathrm{~cm}$ long in climbing stems, 3-5 mm diameter, green with darker spots; adventitious root sparsely produced along the stem. Leaves petiolate; petiole broader than stem, $0.5-2.5 \mathrm{~cm}$ long, $3-5 \mathrm{~mm}$ in diameter, light green to purple; lamina dimorphic, the first type ovate, obovate or oblanceolate, usually almost flat, located along climbing stems, $10-20 \times 5-10 \mathrm{~cm}$, the second type almost round to elliptic, usually convex and forming domatia with 4-10 leaves each 3-7(-10) $\times(2-) 4-5 \mathrm{~cm}$, base cordate with numerous minute basal colleters forming a convex line on the adaxial surface at the base of the lamina, apex acute or acuminate, margins minutely undulate but appearing minutely dentate in the proximal half of the lamina, sometimes entire along the distal part of the lamina; venation pinnate, secondary veins $4-5$ pairs, diverging at c. $70^{\circ}$, anastomosing, tertiary venation reticulate; dark green above with grey to purple spots, below lighter green, occasionally all purple, midrib depressed above, raised below, light green, sometimes purple. Inflorescence positively geotropic, pseudo-umbellate, convex, $2-5$-flowered( -12 flowered in cultivated material); peduncle positively geotropic or ageotropic, $1-2(-5) \mathrm{cm}$ long, $3-5 \mathrm{~mm}$ in diameter, green with dark purple spots, glabrous. Flowers unscented, lasting $4-5$ days in cultivation; pedicel $2.5-4.5 \mathrm{~cm}$ long, $1.5-2 \mathrm{~mm}$ in diameter, white-light green with red spots, glabrous. Calyx lobes ovate, 2-2.5 $\times 1.5-2 \mathrm{~mm}$, light pink to purple, glabrous with ciliate translucent margins, basal colleters one in each calyx lobe sinus, $0.3-0.5 \times$ c. $0.3 \mathrm{~mm}$, ovate to triangular with a round tip. Corolla rotate, concave, with corolla lobe tips inflexed, $2.5-4 \mathrm{~cm}$ in diameter, $4-5 \mathrm{~cm}$ when flattened; corolla lobes almost free, ovate to oblanceolate, 


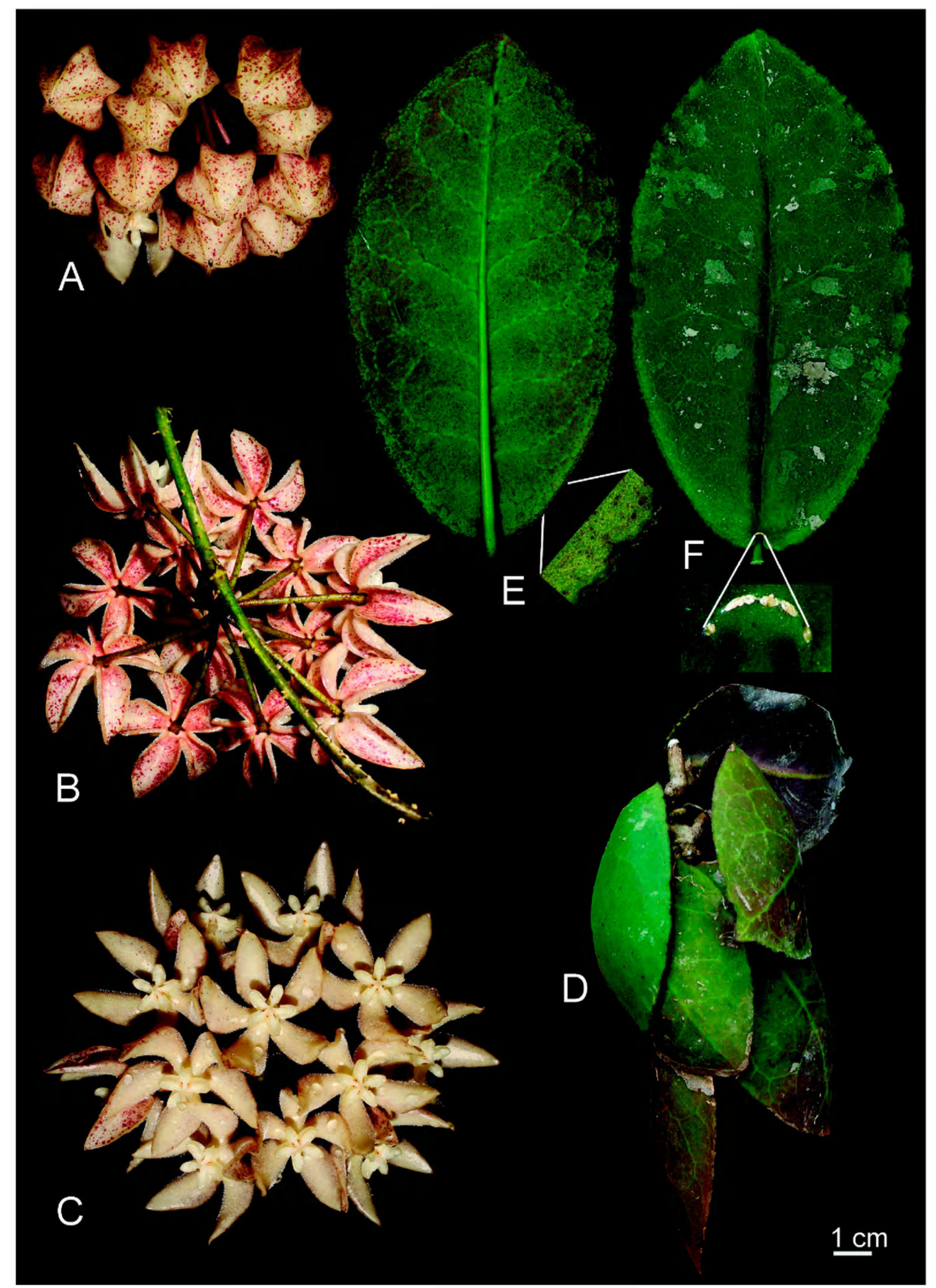

Fig. 1. Hoya undulata S.Rahayu \& Rodda (from M. Rodda MR650, SING) A. Buds. B. Inflorescence, top view. C. Inflorescence from underneath. D. Domatia; E. Leaf, abaxial, with a magnification of the minutely undulate margin. F. Leaf, adaxial, with a magnification of the basal colleters. (Photos: A, B, E, F, Michele Rodda; D, Surisa Somadee) 


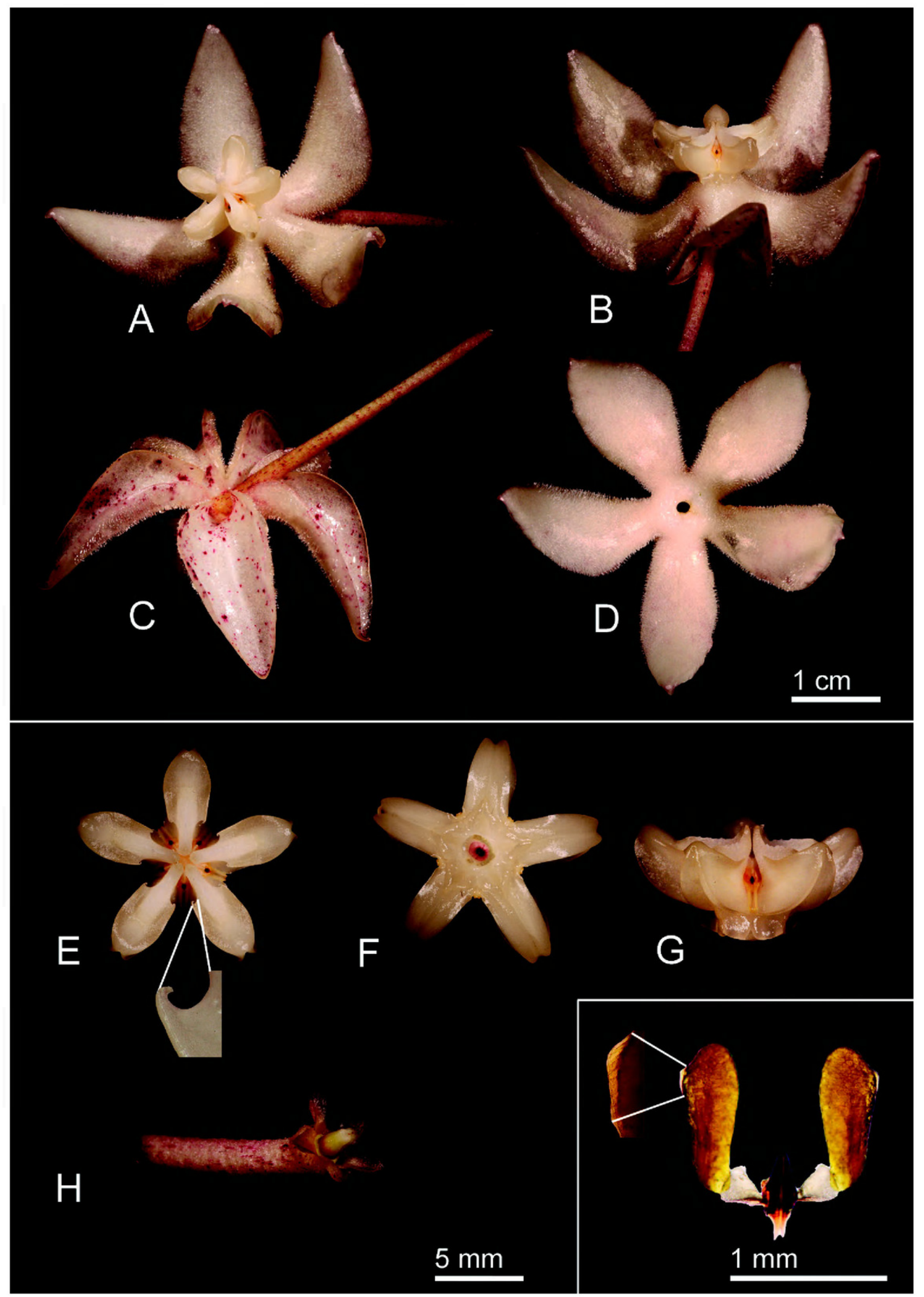

Fig. 2. Hoya undulata S.Rahayu \& Rodda (from M. Rodda MR650, SING). A, B, C. Flower. D. Corolla after removing the corona. E. Corona, top view. F. Corona, from underneath. G. Corona, side view. H. Calyx and ovaries. I. Pollinarium with twin pollinia, with a magnification of the much reduced sterile edge. (Photos: Michele Rodda) 
2-2.5 $\times 1-1.5 \mathrm{~cm}$, white with purple red dots outside, cream-light pink inside, margin recurved predominantly in the proximal half of the lobe, apex acute, curved toward the adaxial surface, pilose inside with glabrous apex, glabrous outside. Corona staminal, 12-13.5 $\mathrm{mm}$ in diameter, 5-7 mm high; lobes spreading, when observed from above clavate, $5.5-6.5 \times 2.5-3 \mathrm{~mm}$, carinate above, below sulcate with revolute margins, outer process concave, inner apex rounded, upcurved, abruptly narrowing into a terete linear inner process with upcurved acuminate tip; two lateral hooked appendages at the junction between outer and inner process. Anthers ovate to almost round, c. $1.5 \times$ $1.5 \mathrm{~mm}$, with apical round membranaceous appendage just exceeding the style-head apex. Pollinia oblong, 900-1000 × 350-400 $\mu \mathrm{m}$, narrowing towards the base, apex round, sterile edge much reduced, limited to the upper outer part of the pollinium; corpusculum rhomboid with acute tips, 500-600 × 200-250 $\mu \mathrm{m}$; caudicle broadly triangular, hyaline, unwinged, 250-300 $\times$ 250-300 $\mu \mathrm{m}$ at the widest. Style-head 5 angled in cross section, with 5 lobes alternating with the stamens, style-head apex round, $1.5 \mathrm{~mm}$ long, c. $3 \mathrm{~mm}$ broad at the base. Ovaries 2, conical with round tip, 1.5-2 $\mathrm{mm}$ long, c. $1 \mathrm{~mm}$ wide at the base, light green, red at the base and at the apex. Fruit and seed not seen.

Distribution. Only known from the type locality in West Kalimantan, close to Putussibau. A second unlocalised collection is widely available in cultivation.

Etymology. The specific epithet refers to the characteristic undulate leaf margin.

Habitat and ecology. Observed in lowland heath forest at 300-380 m above sea level on a slope above a stream, epiphytic on small tree trunks about $1.5 \mathrm{~m}$ above ground, growing in about $80 \%$ humidity and $50 \%$ sunlight. (Sulaiman Hasim pers. comm.). According to the epiphytic zonation by Johansson (1975), the species grows in zone B. The zonation of epiphytes is mainly correlated with their light, nutrients and water requirement. Some species are restricted to strongly illuminated sites, some to shady sites, while some avoid both strong light and deep shade and yet others have a wide range of tolerance (Benzing, 1990). Usually, occupying the B zone means that the species is adapted to moist shady habitats. The leaves of Hoya undulata can adapt to high light levels, but they have been observed to develop a purple colour in intense sunlight. At the type locality, the plants were rooting in ant nests and, on casual observation, the leaf domatia harboured ants.

Provisional IUCN conservation assessment. Known from only one locality, the preliminary conservation status of Hoya undulata is Data Deficient (DD, IUCN 2014). Ex situ collections are present in Bogor Botanic Gardens (from the type locality) and in Singapore Botanic Gardens (SBG acc. no. 20132428).

Notes. Two species, Hoya mitrata, from Thailand, Peninsular Malaysia, Sumatra, Borneo, Sulawesi and Java, and H. darwinii, endemic to the Philippines, both commonly associated with ants (Kleijn \& Donkelaar, 2001), are similar to H. undulata. 


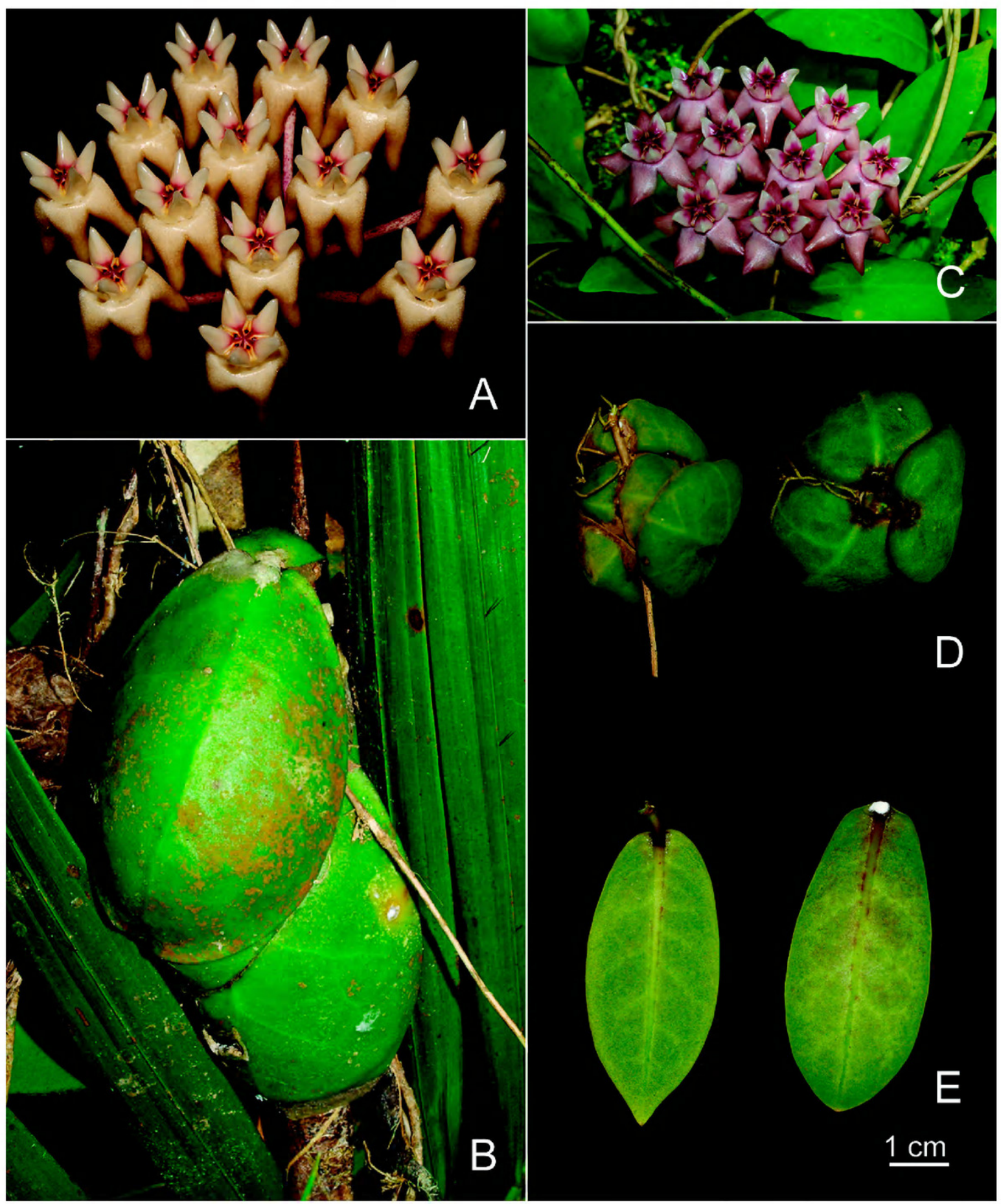

Fig. 3. Hoya mitrata Kerr (Photographed at Gunung Panti, Johor, Malaysia) A. Inflorescence. B. A small domatium. Hoya darwinii Loher (M. Rodda MR421, SING). C. Inflorescence. D. Domatia. E. Leaves not forming domatia. (Photos: Michele Rodda)

In vegetative morphology, the three species have two types of leaves, the first with a flat or slightly convex lamina, occurring at widely spaced nodes on long climbing stems, the other convex, occurring on stems with shorter internodes, and these forming domatia harbouring ant colonies. The first type of leaf is oblong-lanceolate in Hoya 
mitrata and broadly lanceolate in $H$. darwinii, both with an entire edge, while in $H$. undulata it can be ovate, obovate or oblanceolate, with a minutely undulate margin which may appear minutely dentate in the proximal half of the lamina, sometimes entire along the distal part of the lamina. In Hoya darwinii the domatia are globose, 4-7 cm in diameter and formed by 2-6 convex leaves with an inrolled edge (Fig. 3D). The domatia of Hoya mitrata are instead cabbage-shaped, usually larger, formed by tightly clustered broadly obovate convex leaves without inrolled edges (Fig. 3B) (Weissflog et al., 1999; Kleijn \& Donkelaar, 2001). In its natural environment, the domatia of Hoya undulata are generally looser than those of $H$. mitrata or H. darwinii, formed by $4-10$, round to elliptic convex leaves $3-7(-10) \mathrm{cm}$ long, while in cultivation domatia rarely develop and are usually formed by larger leaves (Fig. 1D).

The inflorescences of Hoya darwinii and H. mitrata are flat to slightly convex, negatively geotropic, bearing 10-15 flowers (Fig. 3A, C), the corolla has a tube almost as long as the lobes, and the lobes are reflexed; the outer process of the corona lobes is swollen, erect. The inflorescences of Hoya undulata are also flat to slightly convex but instead positively geotropic (Fig. 1A-C), bear 2-5 flowers (exceptionally 12 in cultivation); the corolla is concave, with almost free lobes, the corona lobes outer process is concave, spreading with an upcurved apex.

The pollinia of Hoya darwinii and H. mitrata do not have a sterile edge, a character that led Kloppenburg (1994) to accommodate both species in the new section Rudimentalia Kloppenb. The pollinaria of Hoya undulata are overall similar to those of $H$. mitrata and $H$. darwinii but its pollinia instead have a sterile edge, albeit much reduced, limited to the upper outer side of the pollinium (Fig. 2I).

A striking similarity can be observed between the corona of Hoya undulata and H. griffithii from mainland Asia. The corona lobes are clavate in both species, with two lateral hooked appendages at the junction between the outer and the inner processes. These appendages have not been documented in any other Hoya species.

A key to separate Hoya darwinii, H. mitrata and H. undulata is provided below.

Other specimens examined. Unlocalised, 30 March 2014, Rodda, M. MR650, collected from material cultivated at the Singapore Botanic Gardens, acc. no. 20132428 (SING).

Key to Hoya species forming domatia

1a. Inflorescence negatively geotropic with 10-15 flowers, outer process of corona

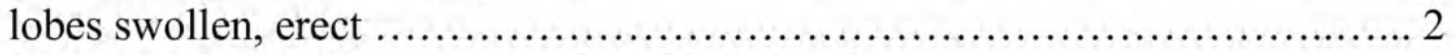

1b. Inflorescence positively geotropic, with 2-5(-12) flowers, outer process of corona lobes concave, spreading with upcurved apex ................... Hoya undulata

2a. Domatia globose, formed by concave leaves with inrolled edges ...................................................... Hoya darwinii

2b. Domatia cabbage-shaped, formed by vaulted leaves without inrolled edges Hoya mitrata 


\section{Lectotypification of Hoya darwinii}

Hoya darwinii Loher, Gard. Chron. 47: 66 (1910). - TYPE: Philippines, Luzon, Rizal Prov., September 1909, Loher, A. 14574 (lectotype UC [UC243291], designated here).

When Loher described Hoya darwinii he did not cite any specimens as belonging to the taxon. He only indicated that the species was collected in Luzon and that it bloomed in March and April. Loher collected in Luzon over a long period of time, from 1889 to 1915 . His specimens collected before 1906 were deposited at K, with substantial sets of duplicates in PNH, US, M, CAL; his collections from 1908 to 1915 (numbers 12000 to 15170) were deposited in PNH (Merrill, 1925), with a first duplicate set sent to $\mathrm{M}$ and additional specimens to UC and A (orchids only) (Steenis-Kruseman, 1950). We have examined Hoya specimens at K, and made enquires to M, UC, PNH and US about the presence of any relevant Loher material. At $\mathrm{K}$ we located numerous early Loher specimens, none identifiable as Hoya darwinii; at M we found post-1908 Loher specimens, once again not belonging to $H$. darwinii. No Hoya darwinii specimens collected by Loher could be found at PNH or US. However, three specimens of Hoya darwinii were found at UC: two duplicates of Loher 14990, collected in Luzon, Rizal Prov., in 1915, one of which is also labelled Bolster 395 (this label should be removed as it likely refers to a different Hoya species with yellow flowers, while $H$. darwinii generally has pink flowers), and Loher 14574, collected in Luzon in September 1909 (Fig. 4). The latter is the only available specimen collected before the publication date of Hoya darwinii and most probably belongs to the original material on which this taxon is based. Thus, it is the only specimen available for lectotypification. However, it must be noted that it does not fully match Loher's description as the flowering period was indicated as March-April. If new evidence were to be found to indicate this specimen is not original material, and in the absence of the discovery of alternative original material, then the lectotypification designated here would count as an effective neotypification under Art. 9.9 of the ICN (McNeill et al., 2012).

ACKNOWLEDGEMENTS. We would like to thank Mr Sulaiman Hasim who provided material of the new species for study and cultivation in Bogor Botanic Gardens; Yoyo Budiman for his assistance in transferring the material, Teguh (BBG) for assistance in pressing the materials and Surisa Somadee, who provided photographs of Hoya undulata. We also thank the curators of BCU, BK, BKF, BM, BO, BRUN, FI, K, KEP, L, LAE, M, P, PNH, SAN, SAR, SNP, SING, UC, US and UPM herbaria for allowing access and/or for providing high quality images of herbarium specimens, an anonymous reviewer and Dr David Middleton, Editor of Gardens' Bulletin Singapore, for suggesting improvements to this manuscript. 


\section{References}

Aurigue, F.B., Sahagun, J.R. \& Suarez, W.M. (2013). Hoya cutis-porcelana (Apocynaceae): A New Species from Samar and Biliran Islands, Philippines. J. Nat. Stud. 12 (1): 12-17.

Benzing, D.H. (1990). Vascular epiphytes: general biology and related biota. Cambridge Univ. Press, Cambridge..

Forster, P.I. (1996). A checklist of the Asclepiadaceae of Papua. Sci. New Guinea 22(1): 15-22.

Forster, P.I., Liddle, D.J., \& Liddle, I.M. (1998). Diversity in the genus Hoya (AsclepiadaceaeMarsdenieae). Aloe 35: 44-48.

Johansson, D.R. (1975). Ecology of epiphytic orchids in West African rain forests. Amer. Orchid Soc. Bull. 44: 125-136.

Kleijn, D. \& van Donkelaar, R. (2001). Notes on the taxonomy and ecology of the genus Hoya (Asclepiadaceae) in Central Sulawesi. Blumea 46: 457-483.

Kloppenburg, R.D. (1994). Hoya sections. Fraterna 1994(1\&2): I-XXIV.

IUCN Standards and Petitions Subcommittee (2014). Guidelines for Using the IUCN Red List Categories and Criteria. Version 10.1. http://www.iucnredlist.org/documents/ RedListGuidelines.pdf (accessed on 20 Jan. 2014).

Lamb, A., Gavrus, A., Emoi, B. \& Gokusing, L. (2014). The hoyas of Sabah, a commentary with seven new species and a new subspecies. Sandakania 19: 1-89.

McNeill, J., Buck, W.R., Demoulin, V., Greuter, W., Hawkworth, D.L., Herendeen, P.S., Knapp, S., Marhold, K., Prado, J., Prud'homme van Reine, W.F., Smith, G.F., Wiersema, J.H. \& Turland, N.J. (2012). International Code of Nomenclature for algae, fungi, and plants (Melbourne Code). Regnum Vegetabile 154. 205 p. Königstein: Koeltz Scientific Books.

Merrill, E.D. (1921). A bibliographic enumeration of Bornean plants. J. Straits Branch Roy. Asiat. Soc., Special Number. Singapore: Fraser \& Neave Ltd.

Merrill, E.D. (1925). New species of Philippine plants collected by A. Loher. Philipp. J. Sci. 27: 21-59.

Rahayu, S. (2006). Keanekaragaman jenis Hoya di Hutan Lindung Bukit Batikap, Pegunungan Muler, Kalimantan Tengah. Biodiversitas 7(2): 139-142.

Rintz, R.E. (1978). The Peninsular Malaysian species of Hoya (Asclepiadaceae). Malayan Nat. J. 30: 467-522.

Rodda, M. (2012). (2074) Proposal to conserve the name Hoya mitrata against $H$. wallichiana (Apocynaceae, Asclepiadoideae). Taxon 61(3): 685-686.

Rodda, M. \& Ercole, E. (2014). Hoya papaschonii (Apocynaceae: Asclepiadoideae), a new species from southern Thailand with a peculiar corona. Phytotaxa 175(2): 097-106.

Rodda, M. \& Simonsson, N. (2011a). Hoya devogelii (Apocynaceae: Asclepiadoideae), a new species from Sarawak, Borneo. Webbia 66(1): 33-38.

Rodda, M. \& Simonsson, N. (2011b). Hoya medinillifolia (Apocynaceae: Asclepiadoideae), a new species from lowland forest of Sarawak, Borneo. Webbia 66(2): 149-154.

Rodda, M. \& Simonsson Juhonewe, N. (2013a). Hoya nuttiana (Apocynaceae:Asclepiadoideae), a new species from Sarawak, Malaysian Borneo. Phytotaxa 140 (1): 56-60.

Rodda, M. \& Simonsson Juhonewe, N. (2013b). The taxonomy of Hoya micrantha and Hoya revoluta (Apocynaceae, Asclepiadoideae). Webbia 68(1): 7-16.

Rodda, M., Simonsson Juhonewe, N. \& Ercole, E. (2013). Hoya corymbosa (Apocynaceae: Asclepiadoideae), a new unusual species from Sabah, Borneo and its systematic position based on phylogenetic analyses. Syst. Bot. 38 (4): 1125-1131. 
Rodda, M., Simonsson Juhonewe, N. \& Rahayu, S. (2014). Taxonomic revision of the Hoya mindorensis complex (Apocynaceae:-Asclepiadoideae). Webbia 69(1): 39-47.

Steenis-Kruseman, M.J. van (1950). Malaysian plant collectors and collections: Being a cyclopaedia of botanical exploration in Malaysia and a guide to the concerned literature up to the year 1950. Flora Malesiana, Ser. 1, 1: 5-605. Jakarta: P. Noordhoff.

Weissflog, A., Moog, J., Federle, W., Wernr, M., Hashim, R. \& Maschwitz, U. (1999). Hoya mitrata Kerr. (Asclepiadaceae): a new myrmecotropic epiphyte from Southeast Asia wih a unique multileaved domatium. Ecotropica 5: 221-225. 


\section{$2 \mathrm{BHL}$ Biodiversity Heritage Library}

Rahayu, S, Meve, U, and Rodda, Michele. 2015. "Hoya undulata (Apocynaceae, Asclepiadoideae), a new myrmecophytic species from Borneo, and typification of H. darwinii." The Gardens' bulletin, Singapore 67(1), 85-94.

https://doi.org/10.3850/s2382581215000095.

View This Item Online: https://www.biodiversitylibrary.org/item/223283

DOI: https://doi.org/10.3850/s2382581215000095

Permalink: https://www.biodiversitylibrary.org/partpdf/229507

\section{Holding Institution}

Singapore Botanic Gardens, National Parks Board Singapore

\section{Copyright \& Reuse}

Copyright Status: In copyright. Digitized with the permission of the rights holder.

License: http://creativecommons.org/licenses/by-nc-sa/4.0/

Rights: https://biodiversitylibrary.org/permissions

This document was created from content at the Biodiversity Heritage Library, the world's largest open access digital library for biodiversity literature and archives. Visit BHL at https://www.biodiversitylibrary.org. 